Article

\title{
Synthesis of Silver Modified Bioactive Glassy Materials with Antibacterial Properties via Facile and Low-Temperature Route
}

\author{
Isabel Gonzalo-Juan ${ }^{1, *}$, Fangtong Xie ${ }^{1}$, Malin Becker ${ }^{1}{ }^{\mathbb{D}}$, Dilshat U. Tulyaganov ${ }^{1,2}{ }^{\mathbb{D}}$, \\ Emanuel Ionescu ${ }^{1}\left(\mathbb{D}\right.$, Stefan Lauterbach ${ }^{3}$, Francesca De Angelis Rigotti ${ }^{4}\left(\mathbb{D}\right.$, Andreas Fischer ${ }^{4,5}$ \\ and Ralf Riedel ${ }^{1}$ \\ 1 Institut für Materialwissenschaft, Technische Universität Darmstadt, Otto-Berndt-Straße 3, \\ D-64287 Darmstadt, Germany; xiefangtong@gmail.com (F.X.); m.l.becker@utwente.nl (M.B.); \\ tulyaganovdilshat@gmail.com (D.U.T.); emanuel.ionescu@tu-darmstadt.de (E.I.); \\ ralf.riedel@tu-darmstadt.de (R.R.) \\ 2 Department of Natural-Mathematical Sciences, Turin Polytechnic University in Tashkent, 17, Small Ring, \\ Tashkent 100095, Uzbekistan \\ 3 Institut für Angewandte Geowissenschaften, Technische Universität Darmstadt, Schnittspahnstrasse 9, \\ D-64287 Darmstadt, Germany; stefan.lauterbach@geo.tu-darmstadt.de \\ 4 Division of Vascular Signaling and Cancer (A270), German Cancer Research Center (DKFZ), \\ Im Neuenheimer Feld 280, 69120 Heidelberg, Germany; f.deangelisrigotti@dkfz-heidelberg.de (F.D.A.R.); \\ andreas.fischer@medma.uni-heidelberg.de (A.F.) \\ 5 Department of Medicine I and Clinical Chemistry, University Hospital of Heidelberg, \\ 69120 Heidelberg, Germany \\ * Correspondence: isabel.gonzalo@tu-darmstadt.de
}

Received: 19 October 2020; Accepted: 11 November 2020; Published: 13 November 2020

check for updates

\begin{abstract}
There is an increasing clinical need to develop novel biomaterials that combine regenerative and biocidal properties. In this work, we present the preparation of silver/silica-based glassy bioactive (ABG) compositions via a facile, fast $(20 \mathrm{~h})$, and low temperature $\left(80^{\circ} \mathrm{C}\right)$ approach and their characterization. The fabrication process included the synthesis of the bioactive glass (BG) particles followed by the surface modification of the bioactive glass with silver nanoparticles. The microstructural features of ABG samples before and after exposure to simulated body fluid (SBF), as well as their ion release behavior during SBF test were evaluated using infrared spectrometry (FTIR), ultraviolet-visible (UV-Vis) spectroscopy, X-ray diffraction (XRD), electron microscopies (TEM and SEM) and optical emission spectroscopy (OES). The antibacterial properties of the experimental compositions were tested against Escherichia coli (E. coli). The results indicated that the prepared ABG materials possess antibacterial activity against $E$. coli, which is directly correlated with the glass surface modification.
\end{abstract}

Keywords: bioactive glass; antibacterial; silver; nanocomposites; E. coli; ion release

\section{Introduction}

Among the different synthetic biomaterials aimed for regenerating bone defects, bioactive glasses attract attention due to their controllable chemical dissolution and bonding to the target tissue facilitating its healing in a relatively short period of time [1-3].

One of the main issues connected to orthopedical surgery are bacterial infections that might lead to implant failure, devastating health complications for the patient, and high treatment costs [4]. Van de Belt et al. [5] reported that, when orthopedic implants are in contact with blood, plasma proteins 
can form a conditioning film on the surface of the implant where microorganisms can easily adhere to. Current efforts are focused on the modification of the surface of bioactive materials with inorganic antibacterial elements to reduce the use of antibiotics and the associated drug resistance issues. Antibacterial properties can be provided to glasses typically by ion exchange either in aqueous solutions or molten salts. Among various inorganic antibacterial agents, silver has been demonstrated as a suitable candidate for the ion exchange approach due to its great ability to enter the silicate glass structure. Moreover, it exhibits a broad-spectrum bactericidal behavior at low concentrations without causing resistant bacteria [6-9], while keeping the bulk structure and main properties of the material mostly unaltered [10-14]. Silver ions can be easily exchanged with the $\mathrm{Na}^{+}$ions of the bioactive glass due to their similarities in ionic radius and valence. Silver ions can be deposited on the surface or penetrate into the glass network, strongly depending on the reaction conditions used for preparing the silver modified materials. Verne et al. [15] demonstrated that silver ions introduced into a bioactive glass $\left(\mathrm{SiO}_{2}-\mathrm{CaO}-\mathrm{Na}_{2} \mathrm{O}\right)$ network and/or deposited on the surface by ion exchange in aqueous solution provided better control of the amount of incorporated silver as compared to the Ag-modified materials prepared by the molten salt approach, which enables avoiding cytotoxic effects [15]. The main issue related to ion exchange in aqueous solutions relates to the associated long reaction times, lasting from days to months [11,15]. In this regard, sonochemistry has been demonstrated as a suitable approach to reduce mainly bulk high temperatures, high pressures, and long reaction times involved in some methods [16]. The production of silver nanoparticles from aqueous silver nitrate solutions sonochemically was investigated by Mănoiu and Aloman [17]. The proposed method consisted of applying a strong flow of ultrasonic energy $[17,18]$ to silver nitrate solutions with concentrations ranging from $0.1 \mathrm{M}$ to $0.001 \mathrm{M}$ at $30^{\circ} \mathrm{C}$ for $1 \mathrm{~h}$. These conditions led the fluid to cavitate (i.e., formation, growth and implosive collapse of bubbles) [19] providing quasi-spherical silver nanoparticles of about $7 \mathrm{~nm}$ average particle size. He et al. [19] reported on the formation of Ag nanoparticles by an ultrasonic approach in acidic, neutral and alkaline aqueous media without using any reductant and surfactant reagent. They proposed that upon sonication of aqueous silver nitrate solution, water molecules decompose to hydrogen and hydroxyl radicals $(\mathrm{H} \cdot$ and $\cdot \mathrm{OH}$, respectively). Finally, H·radicals supply electrons to $\mathrm{Ag}^{+}$which is reduced to metallic silver [19].

In the present work, silver from a $\mathrm{AgNO}_{3}$ solution has been incorporated into the surface of a bioactive glass which contains magnesium, fluorine and features significantly lower sodium content as compared to that of the well-known $45 S 5$ Bioglass $^{\circledR}[20,21]$. The combination of the ion exchange approach with the ultrasonic treatment has been shown to represent a facile, time-saving method to modify the surface of a bioactive glass with Ag. The structural characterization of the Ag-modified glass samples was performed using X-ray diffraction, UV-Vis spectroscopy, TEM and SEM microscopy before and after exposure of the samples to simulated body fluid for several time spans. The antibacterial activity of silver-containing BG has been assessed using E. coli strain.

\section{Materials and Methods}

\subsection{Preparation of Silver-Modified Glass Materials}

The bioactive glass (BG) investigated in this work has the following composition: $4.33 \mathrm{Na}_{2} \mathrm{O}-30.30 \mathrm{CaO}-12.99 \mathrm{MgO}-45.45 \mathrm{SiO}_{2}-2.60 \mathrm{P}_{2} \mathrm{O}_{5}-4.33 \mathrm{CaF}_{2}(\mathrm{~mol} \%)$. It was selected due to beneficial results demonstrated during its application in regenerative biomedicine [20-22]. Fine particles with sizes below $32 \mu \mathrm{m}$ were prepared following the approach reported elsewhere [20-22]. The calculated network connectivity of the BG glass investigated in the present study is about 2.25, and thereby can be considered bioactive according to Hill et al. [23].

Silver-modified (ABG) glassy materials were prepared by a sonochemical method using fine powders of BG and $0.035 \mathrm{M}$ (0.60 wt.\%), 0.077 M (1.25 wt.\%), $0.150 \mathrm{M}(2.50 \mathrm{wt} . \%)$ and $0.220 \mathrm{M}$ (3.70 wt.\%) silver nitrate (ACS reagent, $\geq 99.0 \%$, Sigma Aldrich, St. Louis, MO, USA) solutions. The experimental silver modified ABG materials were further denoted as ABG1, ABG2, ABG3 and ABG4, respectively. 
The solid load of BG powder in the $\mathrm{AgNO}_{3}$ solutions was kept as $10 \mathrm{mg} / \mathrm{mL}$ (i.e., $1 \mathrm{~g}$ of BG was suspended in $100 \mathrm{~mL}$ of solution). To avoid photodegradation, the laboratory ware accommodating silver nitrate solutions and ABG glassy materials was covered by aluminum foil. The procedure for ABG glassy materials preparation is summarized in Scheme 1 and may be described as follows: BG powder was stirred in $\mathrm{AgNO}_{3}$ solutions for 20 min and then a flask with the obtained suspension was placed in the ultrasonic ice-water bath at $35 \mathrm{kHz}$ for $30 \mathrm{~s}$. This procedure of sonochemical treatment was repeated 3 times. Then the sonicated suspensions were heat treated at $80^{\circ} \mathrm{C}$ for $20 \mathrm{~h}$ in air. After centrifugation, the solid was washed with deionized water and dried at $37^{\circ} \mathrm{C}$ for $24 \mathrm{~h}$.

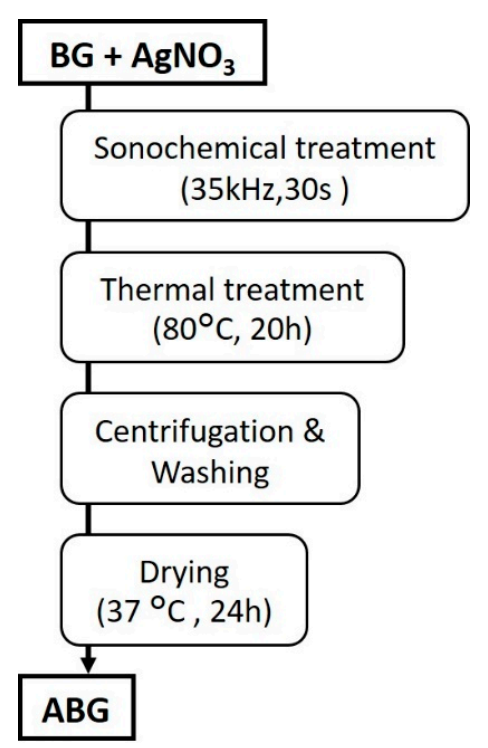

Scheme 1. Proceeding for preparing silver-modified bioactive glass (ABG) materials.

\subsection{Physicochemical Characterization}

X-ray diffraction (XRD) patterns of the as-prepared samples were taken with a STADI P X-ray diffractometer (STOE\&Cie GmbH, Darmstadt, Germany) using Mo K $\alpha$ radiation $(\lambda=0.7093 \AA)$, $45 \mathrm{kV}$ voltage and $30 \mathrm{~mA}$ current. The spectra were performed from $5^{\circ}$ to $40^{\circ}$ in the $2 \theta$ range. For performing the Fourier transform infrared (FTIR) spectroscopy measurement the samples were mixed with $\mathrm{KBr}$ (mass ratio: sample: $\mathrm{KBr}=1: 150$ ) and pressed into a pellet. The spectra were recorded in a 670-IR spectrometer (Varian Inc., Santa Clara, CA, USA) from $400 \mathrm{~cm}^{-1}$ to $4000 \mathrm{~cm}^{-1}$. A JEM $2100 \mathrm{~F}$ transmission electron microscope (JEOL Ltd., Akishima, Tokyo, Japan) was used for generating the high-resolution transmission electron microscopic (HRTEM) images of the ABG samples. Scanning electron microscopy (SEM) analysis was executed on a XL30 FEG (Philips, Chatsworth, CA, USA) under $10-15 \mathrm{kV}$ acceleration voltage. The Ultraviolet-visible diffuse reflectance (UV-vis DR) experiments were recorded at room temperature on a Lambda 900 UV/VIS/NIR Spectrometer (Perkin Elmer, Waltham, MA, USA).

\subsection{In Vitro Acellular Mineralization Tests}

The capability of the silver modified glasses of inducing the formation of calcium phosphate phases onto the glass surfaces, was assessed by soaking $75 \mathrm{mg}$ of the as-prepared samples in $50 \mathrm{~mL}$ of a protein- and cell-free simulated body fluid (SBF) at $37^{\circ} \mathrm{C}$. The SBF solution was prepared according to the procedure described by Kokubo et al. [24]. The experiment (static) was performed in airtight polyethylene flasks, at $37^{\circ} \mathrm{C}$ for: 1 day (1D), 2 days (2D), 3 days (3D), 7 days (7D), 12 days (12D), 14 days (14D), 21 days (21D) and 28 days (28D). At the end of each time period, an aliquot was removed from the sample and the solids were separated from the liquid by filtration. After rinsing the powders with deionized water and acetone, they were characterized by means of 
FTIR, XRD and SEM. The pHs of the filtered solutions were immediately measured and their $\mathrm{Si}, \mathrm{Na}$, $\mathrm{Ca}, \mathrm{Mg}, \mathrm{P}$ and $\mathrm{Ag}$ concentration was determined by using an inductively coupled plasma-optical emission spectrophotometer (Aligent 720 ICP-OES; Aligent, Santa Clara, CA, USA). Additionally, ABG4-chitosan composites were prepared and the same SBF test described before for the silver modified glasses was performed. For the preparation of $1 \mathrm{~g}$ of ABG4-chitosan composite, $20 \mathrm{mg}$ of chitosan (medium molecular weight, Sigma Aldrich, Darmstadt, Germany) were dissolved in aqueous acetic acid. Subsequently, $8.6 \mathrm{mg}$ of ABG4 powder suspended in deionized water were added dropwise, under continuous stirring, to the chitosan solution until a homogeneous composite containing $2 \mathrm{wt} . \%$ chitosan and $0.86 \mathrm{wt} . \%$ ABG4 in $0.1 \mathrm{M}$ acetic acid was obtained.

\subsection{Antibacterial Activity}

Experiments of bactericidal activity have been performed on TOP10 chemically competent Escherichia coli (E. coli, Thermo Fisher Scientific, Waltham, MA, USA). Bacteria were previously transformed and carried a plasmid containing ampicillin-resistance cassette. Therefore, bacteria were resistant to ampicillin, facilitating the handling in non-sterile conditions. By using ampicillin in both culture media and plates, contamination by environmental bacteria is prevented. E. coli were grown at $37^{\circ} \mathrm{C}$ in Luria-Bertani medium (LB medium, Sigma, St. Louis, MO, USA) in presence of ampicillin $(100 \mu \mathrm{g} / \mathrm{mL}$, Sigma, St. Louis, MO, USA) and constantly shaken at 180 RPM.

Two experimental compositions namely ABG3 and ABG4 were sterilized by autoclaving and subsequently added to sterile LB medium (with $100 \mu \mathrm{g} / \mathrm{mL}$ of ampicillin). For comparative purposes the unmodified bioactive glass BG was also tested. Two experiments were performed to investigate the antibacterial activity of the samples.

\subsubsection{Analysis of Bacterial Growth Inhibition}

Ampicilin-resistant E. coli ( $\sim 10^{7}$ colony forming units, CFU) were plated on LB broth agar plates (Sigma, St. Louis, MO, USA) with ampicillin and four areas of the plates were treated with $10 \mu \mathrm{L}$ of BG and silver-modified BG glass particulates $(200 \mathrm{mg} / \mathrm{mL})$. Upon incubation at $37^{\circ} \mathrm{C}$ for $24 \mathrm{~h}$, plates were analyzed for signs of bacterial growth inhibition. Bacteria grow until covering all the surface of the plate with a semitransparent/white layer. When an area is treated with a growth inhibition factor, it remains transparent, due to the absence of bacterial growth.

\subsubsection{Analysis of Bactericidal Action over Time}

Experiment was performed in 96-well plates with U-bottom shape. Ampicilin-resistant E. coli were cultured in a total volume of $200 \mu \mathrm{L}$, which consisted of $100 \mu \mathrm{L}$ of bacteria inoculum and $100 \mu \mathrm{L}$ of glass particulates solution $(20 \mathrm{mg} / \mathrm{mL})$. Therefore, the final working concentration of glass particulates was $10 \mathrm{mg} / \mathrm{mL}$. Amount of bacteria was evaluated by CFU at the moment of the inoculum, and after $1 \mathrm{~h}, 2 \mathrm{~h}$ and $4 \mathrm{~h}$ of incubation at $37^{\circ} \mathrm{C}$ with glass particulates. To calculate the $\mathrm{CFU}$, bacteria were vortexed to have a solution of single bacteria and serial dilutions (1:10 for 6 times) were plated on LB broth agar plates (with $100 \mu \mathrm{g} / \mathrm{mL}$ of ampicillin) for $24 \mathrm{~h}$ at $37^{\circ} \mathrm{C}$. After incubation, the plates in which colonies were overlapping (too low dilution) and the ones in which no colonies appeared (too high dilution) were discarded. On the remaining plates, number of colonies was counted and multiplied for the appropriate dilution factor (depending on the serial dilution) to obtain number of bacteria (CFU).

The statistical differences between experimental conditions were calculated according to the Student's $t$-test of Graph Pad software (Prism 8 version). The samples were considered significantly different when the $p$ value was less than 0.05 . 


\section{Results and Discussion}

\subsection{Chemical and Microstructural Characterization of Silver Modifed Glasses (ABG)}

The XRD patterns of the samples investigated within this study are shown in Figure 1a. The XRD patterns indicate that BG is X-ray amorphous, where a broad hump centered at approximately $13^{\circ}$ is assigned to the amorphous silica network. The prepared ABG glassy materials are of amorphous nature as well, thus, the reflections with low intensity observed in the XRD patterns may be ascribed to crystalline silver (I, II, and III) oxide phases $\left(\mathrm{Ag}_{2} \mathrm{O}, \mathrm{Ag}_{3} \mathrm{O}_{4}\right.$, and $\left.\mathrm{Ag}_{3} \mathrm{O}\right)$ [25-27] and elemental silver (Ag) [28]. The presence of elemental Ag was also corroborated by UV-Vis spectroscopy. Figure $1 \mathrm{~b}$ shows the UV-Vis spectra of the ABG glassy samples prepared using solutions with different concentrations of silver nitrate. Silver nanoparticles (NPs) interact with light strongly due to their known surface plasmon resonance (SPR) [29]. Typically, the SPR peak of the Ag NPs is located between $390 \mathrm{~nm}$ to $476 \mathrm{~nm}$. The absorption bands of the ABG samples are located in the visible range (from ca. $350 \mathrm{~nm}$ to $550 \mathrm{~nm}$ ) with the plasmon peak centered at $392 \mathrm{~nm}$. The detection of the SPR peak, which was not present in the parent glass (BG), confirms the presence of the elemental silver in all as-prepared ABG samples [19].
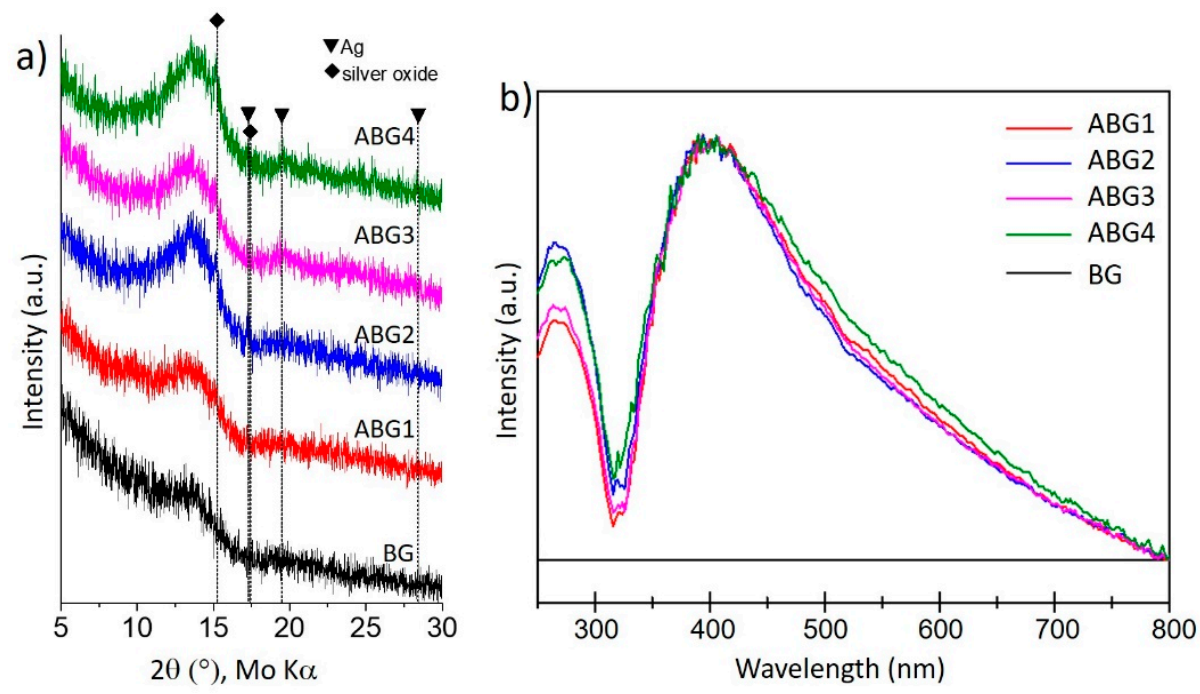

Figure 1. (a) X-ray diffraction patterns and; (b) UV-Vis spectra of the as-prepared silver modified ABG glassy materials and the parent glass BG (black solid line). Peak centered at $392 \mathrm{~nm}$ corresponds to the characteristic SPR peak of silver nanoparticles on the surface of the silver glassy materials. This peak is no detected in the spectrum of the parent glass BG.

The HRTEM image (Figure 2a) reveals the presence of silver nanospheres with an approximate mean diameter of $10 \mathrm{~nm}$. These nanospheres tend to aggregate on the surface of the glass forming silver clusters of different sizes with quasi-spherical shapes (Figure 2b). Some case studies related to the Ag incorporation into the surface of bioglasses reported on the presence of needle-shaped Ag clusters, which were discussed within the context of possibly damaging the cell walls of the bacteria and consequently inhibiting their activity [30]. However, as the silver clusters in the present study are spherical, one may expect that physical damages of the cell walls are rather unlikely. 

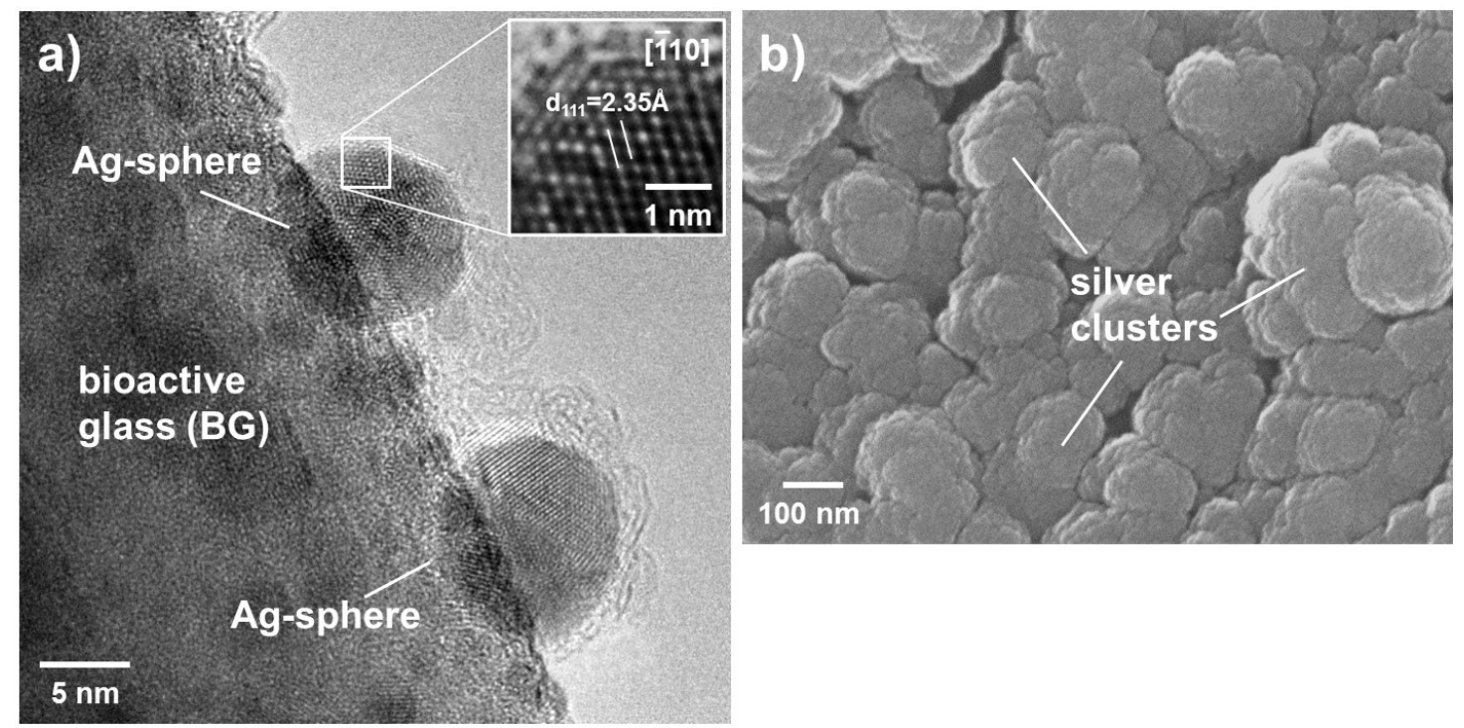

Figure 2. (a) HRTEM micrograph of ABG3 showing that the surface of BG is covered by silver nanoparticles of about $10 \mathrm{~nm}$ and; (b) HR-SEM micrograph of the surface of ABG2.

One question that may arise at this point is regarding the origin of elemental silver. Since neither natural nor chemical reductants have been directly used during the preparation of the ABG samples, most likely, silver nanoparticles were formed during the sonochemical treatment. It is known that the ultrasonic irradiation of the $\mathrm{H}_{2} \mathrm{O}$ generates highly reactive species (mainly $\mathrm{H} \cdot$ and $\cdot \mathrm{OH}$ ) which might be responsible for reducing silver ions to elemental silver [19]. On one hand, according to He et al. [19], the reductive rate of $\mathrm{Ag}^{+}$in pure water via ultrasonic irradiation is very low; however, it may be enhanced by increasing the concentration of $\mathrm{OH}^{-}$in the fluid. It is known that when silicate glasses, like the bioactive glass investigated in the present work, are in contact with water ion exchange reactions between modifiers (such as $\mathrm{Na}^{+}, \mathrm{Ca}^{2+}$ and $\mathrm{Mg}^{2+}$ ) and $\mathrm{H}^{+}$from the surrounding fluid take place at the glass/liquid interface leading to a local (near the surface) increase of the concentration of $\mathrm{OH}^{-}$[31]. $\mathrm{AgNO}_{3}$ in alkaline media forms $\mathrm{Ag}(\mathrm{OH})_{\mathrm{x}}$ species in equilibrium with $\mathrm{Ag}_{2} \mathrm{O}$ [32,33], whose presence in the silver modified glasses has been shown by X-ray diffraction (Figure 1a). Then, upon performing ultrasonic conditioning $\mathrm{Ag}_{2} \mathrm{O}$ crystalline phases are reduced to metallic silver [19]. Contemporarily, that does not exclude the fact that along the procedures involved silver ions may be exchanged with $\mathrm{Na}^{+}$ions in the upper atomic layers of the BG, as demonstrated by Verne et al. [15].

The mid infrared spectra of the investigated samples, prepared with increasing silver content from 0 to $3.7 \mathrm{wt.} \%$ (Figure 3a), exhibit transmittance bands attributed to characteristic vibrations of $\mathrm{SiO}_{4}$ tetrahedron units with different number of bridging oxygen (BO) atoms. The band located at high wavenumbers (from $1200 \mathrm{~cm}^{-1}$ to $850 \mathrm{~cm}^{-1}$ ) is ascribed to the $\mathrm{Si}-\mathrm{O}$ asymmetric stretching mode of the non-bridging oxygens (NBOs) [34,35]. It shows that the network mainly features $\mathrm{Q}^{2}$ species $\left(\mathrm{SiO}_{4}\right.$ sites with $2 \mathrm{BO}$ and $\left.2 \mathrm{NBOs}\right)$ along with $\mathrm{Q}^{3}$ groups $\left(\mathrm{SiO}_{4}\right.$ sites with $3 \mathrm{BOs}$ and one NBO) $[22,36]$. The bands located at lower wavenumbers are ascribed to bending vibrations of the same units (bands between 730 and $800 \mathrm{~cm}^{-1}$ ) and to rocking motion of Si-O-Si units (bands between 400 and $550 \mathrm{~cm}^{-1}$ ) [22]. The structure of all silver-modified glasses investigated is similar to that of the parent glass BG, which indicates that the silver treatment performed within this work does not significantly alter the glass network. 

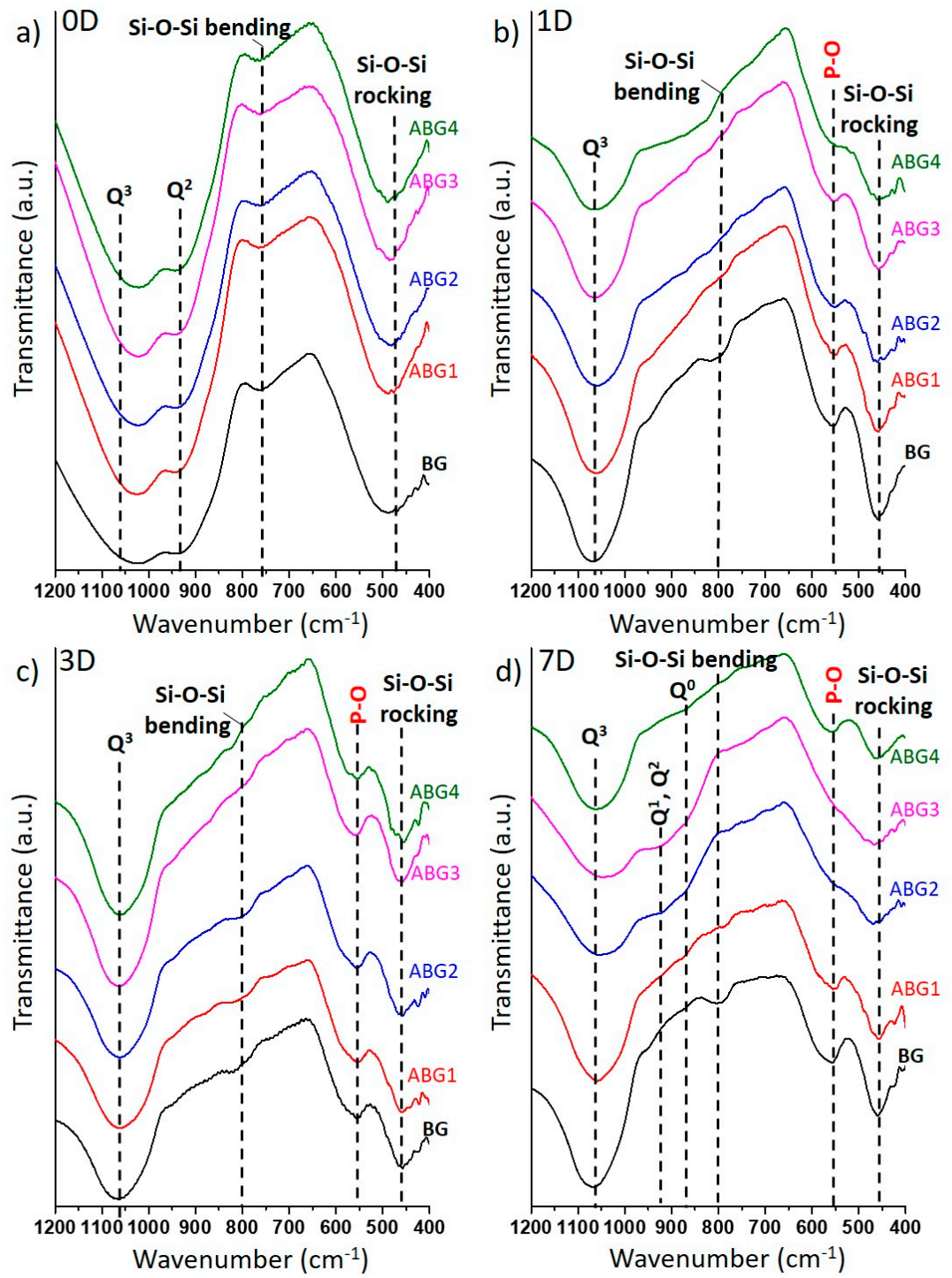

Figure 3. Mid infrared spectra of the ABG1, ABG2, ABG3, and ABG4 glassy materials and parent BG glass upon SBF exposure for (a) 0 days (0D); (b) 1 day (1D); (c) 3 days (3D); and (d) 7 days (7D).

\subsection{In Vitro Acellular Mineralization Assessments of the Silver Modified Glasses}

The formation of apatite upon exposure the glasses in SBF as well as the bacteria growth are strongly $\mathrm{pH}$ dependent [37]. Thus, $\mathrm{pH}$ evolution for $\mathrm{BG}$ and for $\mathrm{ABG}$ materials in $\mathrm{SBF}$ at $37^{\circ} \mathrm{C}$ for different periods of time was monitored. The $\mathrm{pH}$ of the $\mathrm{SBF}$ solution was fixed as $7.4 \pm 0.1$. As shown in Figure 4, compared to the parent BG, in all ABG glassy materials the $\mathrm{pH}$ demonstrated much faster increase, while this tendency was less pronounced after 1 day of immersion. The maximum $\mathrm{pH}$ values recorded for the silver modified samples were $8.0 \pm 0.1$ after $72 \mathrm{~h}$ of immersion (Figure 4 ). The observed increase about $0.6 \mathrm{pH}$ units is relatively low in contrast with the increase observed for the benchmark $45 \mathrm{~S} 5$ which rises the $\mathrm{pH}$ of the SBF solution above $1 \mathrm{pH}$ units [24]. The lower increment observed might be associated with the fluoride ions that are part of the BG used within this work. While the cations such as $\mathrm{Na}^{+}, \mathrm{Ca}^{2+}$ and $\mathrm{Mg}^{2+}$ from the glass surface are leached out from the glass to the solution and replaced by $\mathrm{H}^{+}, \mathrm{F}^{-}$ions are exchanged with $\mathrm{OH}^{-}$ions, thus depleting the concentration of hydroxide ions in the solution and buffering the effect of alkali/ alkaline earth ions [23]. In spite of that, one can notice that the $\mathrm{pH}$ values of the silver modified glasses are always beyond the values gathered for the parent glass. This fact might be associated with the release of silver ions during the first hours of immersion according with the evolution of silver concentration in the fluid over the 
time (Figure $5 \mathrm{f}$ ) which will be explained in detail below: silver ions from the surface are exchanged with hydrogen cations from the solution, thus increasing the concentration of hydroxide anions in the solution. Conversely, the parent $\mathrm{BG}$ exhibited lower $\mathrm{pH}$ values with a plateau after the first hours of immersion until 2 days of immersion, followed by further decline.

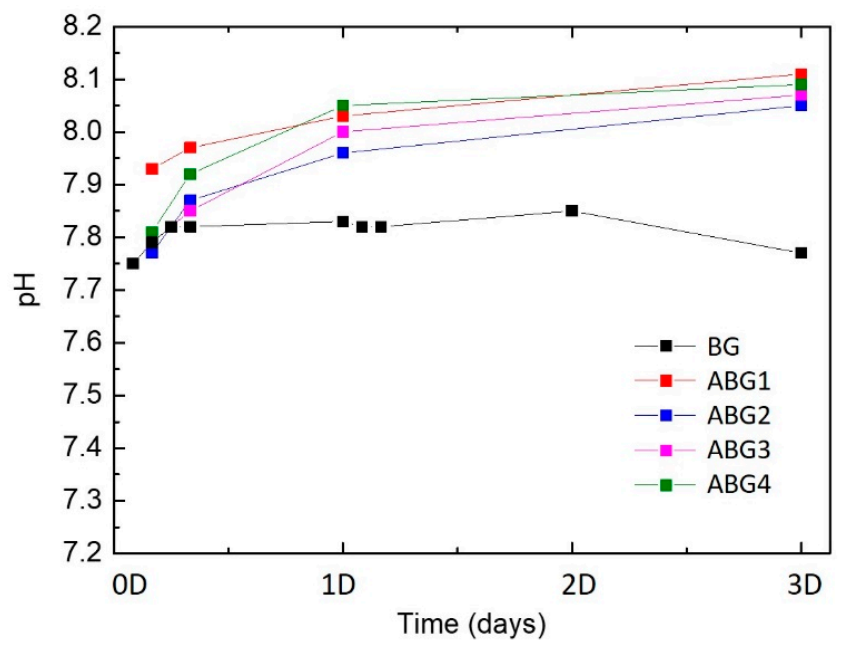

Figure 4. Evolution of $\mathrm{pH}$ upon immersing ABG nanocomposites for different time spans.

a)

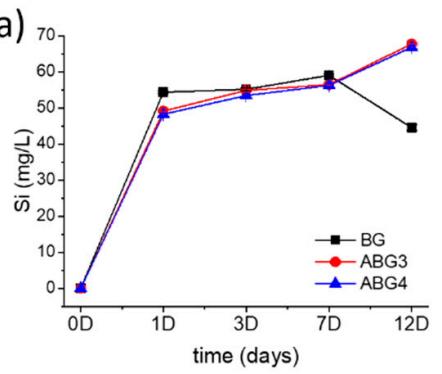

d)

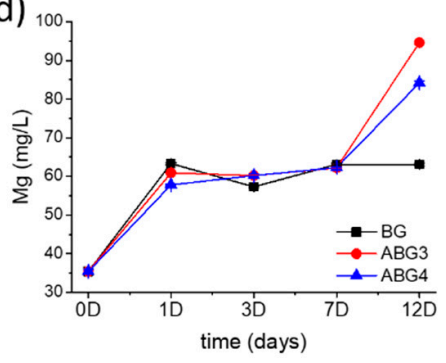

b) 3200

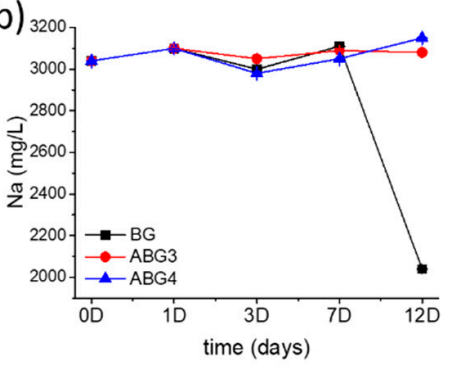

e)

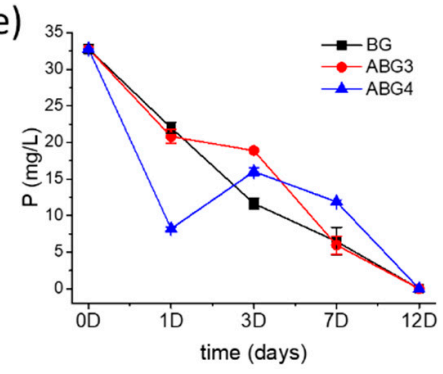

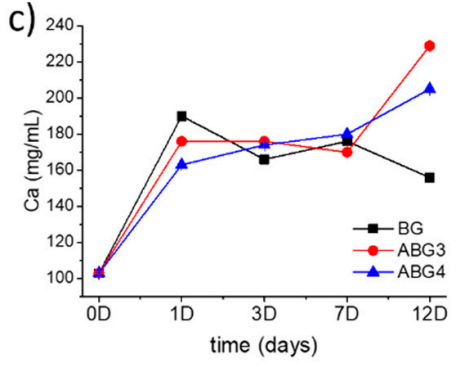

f)

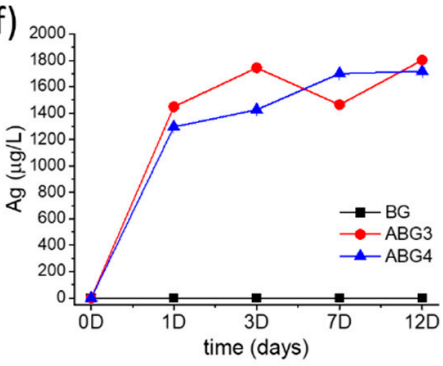

Figure 5. Evolution of the concentration of (a) $\mathrm{Si}$; (b) $\mathrm{Na}$; (c) $\mathrm{Ca}$; (d) $\mathrm{Mg}$; (e) $\mathrm{P}$; and (f) $\mathrm{Ag}$ in SBF solution upon immersing $\mathrm{ABG}$ nanocomposites for different time spans.

Figure 3 illustrates mid infrared spectra obtained for the investigated materials upon exposure in SBF for 0 days (0D, Figure 3a), 1 day (1D, Figure 3b), 3 days (3D, Figure 3c), and 7 days (7D, Figure 3d). The spectra of the soaked samples clearly show that the band attributed to $\mathrm{Q}^{2}\left(\mathrm{SiO}_{4}\right.$ sites with $2 \mathrm{BO}$ and 2 NBOs) disappeared, while the broad band ascribed to Si-O-Si rocking motions gets narrower. Bands related to the $\mathrm{Si}-\mathrm{O}$ asymmetric stretching mode of the $\mathrm{NBO}$ (namely, $\mathrm{Q}^{2}, \mathrm{Q}^{1}$, and $\mathrm{Q}^{0}$ ) are detected only in the silver modified glasses after exposure in SBF (Figure 3b-d). Moreover, a single peak at $\sim 560 \mathrm{~cm}^{-1}$, ascribed to $\mathrm{P}-\mathrm{O}$ bending vibrations, can be observed in the spectra of both silver-modified and silver-free glasses from the beginning of the test. Since only a broad single peak is observed it may suggest the presence of amorphous, rather than crystalline, calcium phosphate phases [38].

The evolution of the ion concentration during the SBF test was assessed by optical emission spectroscopy. The leaching profiles of $\mathrm{Si}, \mathrm{Na}, \mathrm{Ca}, \mathrm{Mg}, \mathrm{P}$ and $\mathrm{Ag}$ are shown in Figure 5 . It can be 
observed that the silicon, sodium, calcium, and magnesium concentrations evolve similarly in both ABG materials and silver-free parent glass during the first week of immersion. However, during the second week of exposure in $\mathrm{SBF}$, the concentration of $\mathrm{Si}, \mathrm{Na}, \mathrm{Ca}$ and $\mathrm{Mg}$ increased in the ABG compositions while it was constant (e.g., $\mathrm{Mg}$ ) or even decreased (e.g., $\mathrm{Si}, \mathrm{Na}$, and $\mathrm{Ca}$ ) in the parent glass.

It is well documented that the removal of phosphorous from SBF solution is attributed to the precipitation of phosphate species on the glass surface. It can be observed that while the parent glass demonstrates a smooth decrease in phosphorus concentration, the ABG samples show more abrupt profiles. Importantly, the Ag leaching profiles in ABG samples (Figure 5f) suggest abrupt growth in Ag ion concentration during the first hours till 1 day of immersion with steady increase in silver concentration along all 12 days of immersions (with the exception revealed for 7 days of immersion in ABG4).

The mineralization of bioactive glasses is typically investigated by the observation of amorphous and crystalline calcium phosphate developed on the glass surface upon immersion in SBF solution. Figure 6 shows XRD patterns of sample ABG4 after immersion in SBF solution for different periods of time that revealed characteristic diffraction peaks of $\mathrm{AgCl}$ (ID \#: 00-031-1238) [15]. As stated in the literature [15], during the SBF test, $\mathrm{ABG} 4$ releases $\mathrm{Ag}^{+}$ions which speedily react with the chlorides from the SBF solution leading to the precipitation of insoluble $\mathrm{AgCl}$ crystals on the surface of the glass. Moreover, the $\mathrm{AgCl}$ crystals on the surface may prevent the direct contact between the surface of the glass and the liquid phase leading to a reduction of the release rate of silver ions as can be shown in the evolution of the concentration of silver from 1 day of immersion in the fluid (Figure $5 \mathrm{f}$ ).

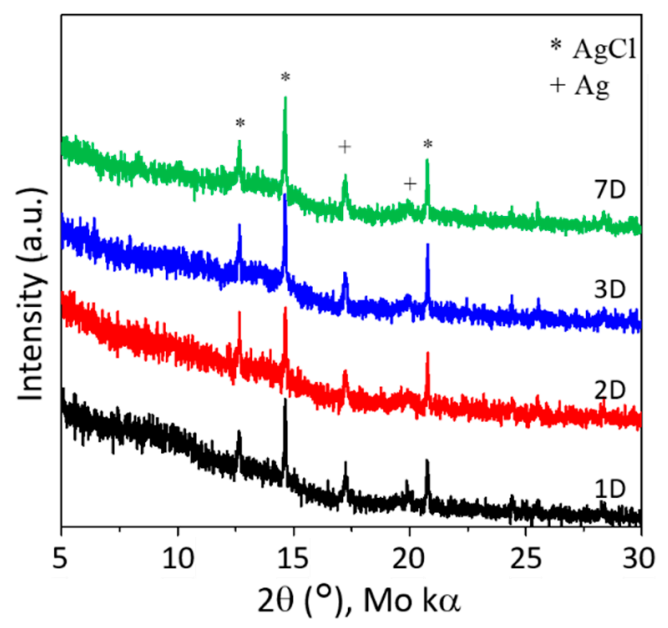

Figure 6. XRD patterns of ABG4 as-prepared upon exposure in SBF for different periods of time.

However, the SEM micrographs of the as-prepared ABG4 glass upon immersion in SBF for 2 weeks (Figure 7) shown some cauliflower facets characteristic of hydroxyapatite (HA). Then, we may conclude that the most intense diffraction peak of $\mathrm{AgCl}$ at $14.69^{\circ}$ overlaps with the main peak of HA masking the presence of calcium phosphate crystalline phases. 

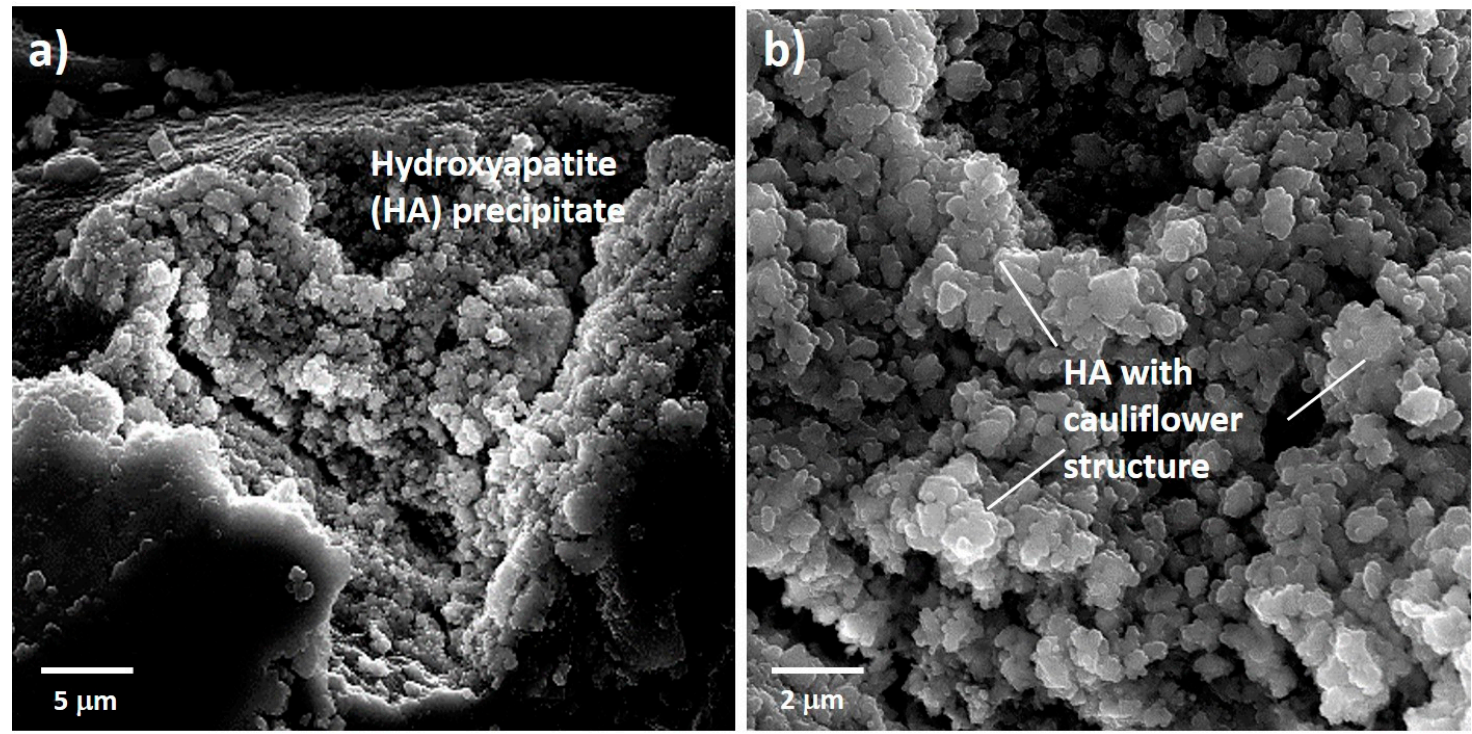

Figure 7. SEM micrographs of ABG4 upon immersion in SBF for 2 weeks at (a) 3000 times magnification and (b) 10000 times magnification.

This issue was partially solved by incorporation of chitosan as a silver chelating agent. It is well established that chitosan as a polysaccharide biopolymer exhibits excellent chelating properties with metals and semiconductors due to the presence of both amino and hydroxyl groups in its monomers [39]. Then, ABG4 glass was embedded in $2 \mathrm{wt} . \%$ chitosan [39] and subsequently immersed in SBF for different time spans. The XRD diffraction patterns of the ABG4-BG composite before and after immersion in SBF (for 1D, 14D, and 21D) are shown in Figure 8. Before immersion in SBF (0D), a weak reflection of $\mathrm{Ag}$ was observed at $17.24^{\circ}$ [40], which disappeared over the first hours. For all immersions lasting longer than $1 \mathrm{D}$, the diffraction patterns showed reflections at $14.40^{\circ}, 14.57^{\circ}$, and $14.77^{\circ}$ together with intensive amorphous background which can be assigned to the characteristics reflections of hydroxyapatite (HA) [37]. Accordingly, incorporation of chitosan upon SBF testing of silver modified bioactive glass was shown to be an appropriate approach to reaffirm HA crystals formation.

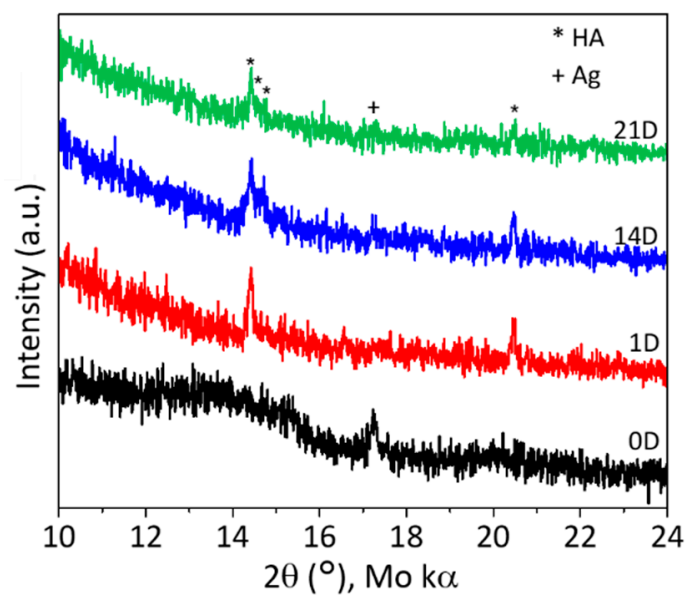

Figure 8. XRD patterns of ABG4 embedded in $2 \mathrm{wt}$.\% chitosan upon exposure in SBF for different periods of time.

\subsection{Bactericidal Activity of the As-Prepared of the Silver Modified Glasses}

To evaluate the bactericidal properties of the silver modified glasses, two different experiments were performed: Inhibition of bacterial growth and bactericidal activity. Figure 9a shows the inhibition 
of bacterial growth in the presence of the silver-containing as well as silver-free bioactive samples. It can be clearly observed that the silver-modified glassy materials (ABG3 and ABG4) inhibited bacterial growth, as revealed by the presence of four clean areas in the respective plates, while the silver-free BG sample shows a uniform bacterial growth. The bactericidal activity of the silver-modified samples over time is depicted in Figure 9b. Samples treated with silver-modified glasses showed a reduction of almost two orders of magnitude in bacterial number after one hour as compared to the silver-free BG sample $(p<0.05)$. Moreover, the number of bacteria treated with silver containing glasses decreased continuously up to reaching the detection limit after ca. $1.5 \mathrm{~h}$ and ca. $2 \mathrm{~h}$ for ABG4 and ABG3, respectively. Finally, samples treated with silver-free BG showed a slight decrease of bacterial number after one hour compared with the inoculum. However, after two hours of incubation at $37^{\circ} \mathrm{C}$, the number of bacteria increased to be comparable to the one of the inoculum. After four hours, the number of bacteria was one order of magnitude higher than that of the inoculum, indicating that BG has no bactericidal properties. The decrease of the number of bacteria observed in the silver free sample during the first hours of the analysis may be due to the release of $\mathrm{F}^{-}$ions [41,42]. In conclusion, the silver-modified ABG glassy materials showed strong bactericidal activity against $E$. coli, which was not observed in the case of the silver-free parent BG.
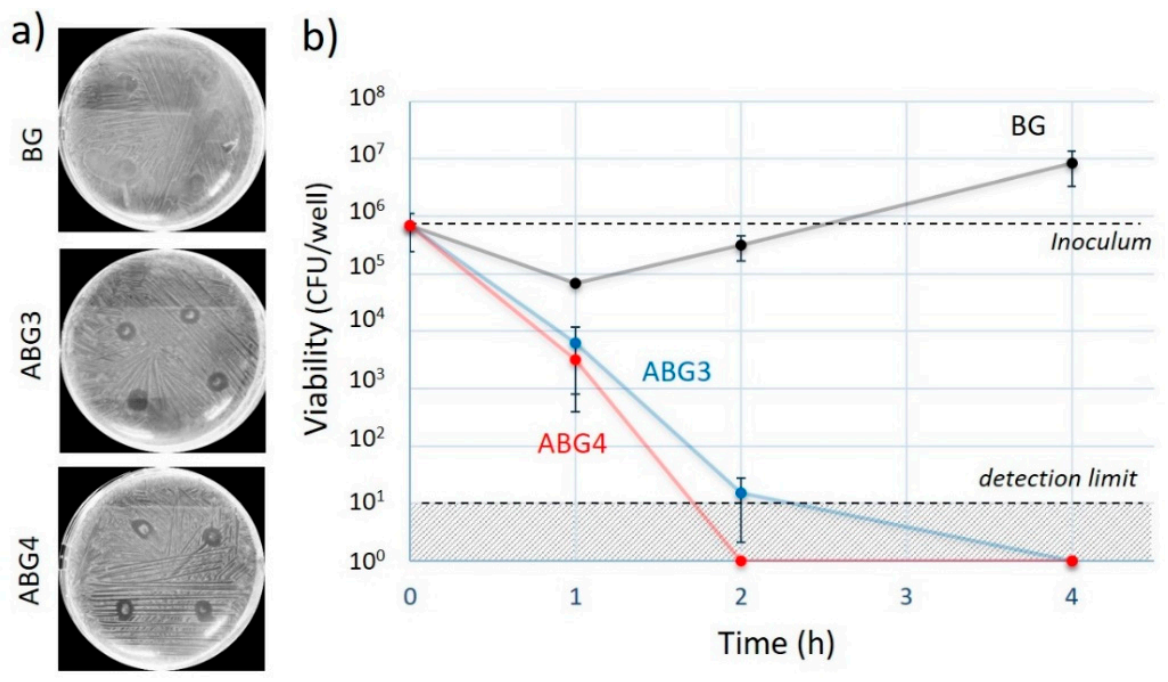

Figure 9. (a) Inhibition of bacterial growth in petri dishes by contact with ABG3 and ABG4 samples; and (b) bactericidal activity of ABG3 and ABG4 materials in LB broth after $1 \mathrm{~h}, 2 \mathrm{~h}$, and $4 \mathrm{~h}$.

\section{Conclusions}

The present study demonstrates that silver nanoparticles with sizes lower than $10 \mathrm{~nm}$ may be incorporated into the surface of BG glass using a facile, fast, and low-temperature synthesis route. According to the mid infrared spectra, the structure of ABG materials is similar to that of the parent glass BG, which indicates that the treatment performed within this work does not significantly alter the structure of the glass network, and thus does not interfere with its bioactivity process mechanisms.

Antibacterial tests showed that the silver-containing glasses, unlike the parent BG, inhibit the growth of E. coli. and exhibit rapid decrease in its viability, reaching the limit of detection after a maximum of $2 \mathrm{~h}$.

Author Contributions: Conceptualization, D.U.T., I.G.-J. and, E.I.; methodology, D.U.T., I.G.-J., S.L., F.D.A.R. and A.F.; software, I.G.-J., F.X. and M.B.; validation, I.G.-J., F.X., M.B., F.D.A.R. and A.F.; formal analysis, I.G.-J., F.X., M.B. and F.D.A.R.; writing — original draft preparation, I.G.-J.; writing—review and editing, D.U.T., I.G.-J. and E.I.; project administration, D.U.T., I.G.-J., E.I. and R.R.; funding acquisition, I.G.-J., E.I. and R.R. All authors have read and agreed to the published version of the manuscript. 
Funding: We acknowledge support by the German Research Foundation and the Open Access Publishing Fund of Technical University of Darmstadt. D.U.T. acknowledges financial support from the Alexander von Humboldt Foundation. E.I. acknowledges funding from the DFG within the Heisenberg program (IO 64/14-1).

Acknowledgments: The authors thank M. Jamil (Institut für Materialwissenschaft, Technische Universität Darmstadt, Germany) for his assistance in characterizing the nanocomposites as well as C. Scholz (Institut für Geowissenschaften, Ruprecht-Karls-Universität Heidelberg, Germany) for performing ICP-EOS analysis.

Conflicts of Interest: The authors declare no conflict of interest.

\section{References}

1. Best, S.M.; Porter, A.E.; Thian, E.S.; Huang, J. Bioceramics: Past, present and for the future. J. Eur. Ceram. Soc. 2008, 28, 1319-1327. [CrossRef]

2. Day, R.M. Bioactive glass stimulates the secretion of angiogenic growth factors and angiogenesis in vitro. Tissue Eng. 2005, 11, 768-777. [CrossRef]

3. Clare, A. Bio-Glasses. An Introduction; Jones, J.R., Clare, A.G., Eds.; Wiley: Chichester, UK, 2012; ISBN 978-0-470-71161-3.

4. Lu, H.; Liu, Y.; Guo, J.; Wu, H.; Wang, J.; Wu, G. Biomaterials with Antibacterial and Osteoinductive Properties to Repair Infected Bone Defects. Int. J. Mol. Sci. 2016, 17, 334. [CrossRef]

5. $\quad$ van de Belt, H.; Neut, D.; Schenk, W.; van Horn, J.R.; van der Mei, H.C.; Busscher, H.J. Infection of orthopedic implants and the use of antibiotic-loaded bone cements. A review. Acta Orthop. Scand. 2001, 72, 557-571. [CrossRef] [PubMed]

6. Swathy, J.R.; Sankar, M.U.; Chaudhary, A.; Aigal, S.; Anshup; Pradeep, T. Antimicrobial silver: An unprecedented anion effect. Sci. Rep. UK 2014, 4, 7161. [CrossRef] [PubMed]

7. You, C.; Han, C.; Wang, X.; Zheng, Y.; Li, Q.; Hu, X.; Sun, H. The progress of silver nanoparticles in the antibacterial mechanism, clinical application and cytotoxicity. Mol. Biol. Rep. 2012, 39, 9193-9201. [CrossRef] [PubMed]

8. Chaloupka, K.; Malam, Y.; Seifalian, A.M. Nanosilver as a new generation of nanoproduct in biomedical applications. Trends Biotechnol. 2010, 28, 580-588. [CrossRef]

9. Kim, J.S.; Kuk, E.; Yu, K.N.; Kim, J.-H.; Park, S.J.; Lee, H.J.; Kim, S.H.; Park, Y.K.; Park, Y.H.; Hwang, C.-Y.; et al. Antimicrobial effects of silver nanoparticles. Nanomed. Nanotechnol. Biol. Med. 2007, 3, 95-101. [CrossRef]

10. Kaya, S.; Cresswell, M.; Boccaccini, A.R. Mesoporous silica-based bioactive glasses for antibiotic-free antibacterial applications. Mat. Sci. Eng. C-Mater. 2018, 83, 99-107. [CrossRef]

11. Negas, T.; Hilfiker, D.; Bartkowski, S. Simple methods to incorporate silver and copper generate antimicrobial glasses and porous glass-bonded ceramics. Am. Ceram. Soc. Bull. 2017, 96, 26-31.

12. Balagna, C.; Vitale-Brovarone, C.; Miola, M.; Verné, E.; Canuto, R.A.; Saracino, S.; Muzio, G.; Fucale, G.; Maina, G. Biocompatibility and Antibacterial Effect of Silver Doped 3D-Glass-Ceramic Scaffolds for Bone Grafting. J. Biomater. Appl. 2011, 25, 595-617. [CrossRef] [PubMed]

13. Verné, E.; Ferraris, S.; Miola, M.; Fucale, G.; Maina, G.; Martinasso, G.; Canuto, R.A.; Di Nunzio, S.; Vitale-Brovarone, C. Synthesis and characterisation of bioactive and antibacterial glass-ceramic Part 1-Microstructure, properties and biological behaviour. Adv Appl. Ceram. 2008, 107, 234-244. [CrossRef]

14. Bellantone, M.; Williams, H.D.; Hench, L.L. Broad-spectrum bactericidal activity of Ag2O-doped bioactive glass. Antimicrob. Agents. Chemother. 2002, 46, 1940-1945. [CrossRef] [PubMed]

15. Vernè, E.; Di Nunzio, S.; Bosetti, M.; Appendino, P.; Vitale Brovarone, C.; Maina, G.; Cannas, M. Surface characterization of silver-doped bioactive glass. Biomaterials 2005, 26, 5111-5119. [CrossRef]

16. Xu, H.; Zeiger, B.W.; Suslick, K.S. Sonochemical synthesis of nanomaterials. Chem. Soc. Rev. 2013, 42, 2555-2567. [CrossRef]

17. Mănoiu, V.S.; Aloman, A. Obtaining silver nanoparticles by sonochemical methods. UPB. Sci. Bull. B 2010, 72, 179-186.

18. Cheng, J.; Yao, S.; Zhang, W.; Zou, Y. Preparation and characterization of silver colloids with different morphologies under ultrasonic field. Front. Chem. 2006, 1, 418-422. [CrossRef]

19. He, C.; Liu, L.; Fang, Z.; Li, J.; Guo, J.; Wei, J. Formation and characterization of silver nanoparticles in aqueous solution via ultrasonic irradiation. Ultrason. Sonochem. 2014, 21, 542-548. [CrossRef] 
20. Tulyaganov, D.U.; Agathopoulos, S.; Valerio, P.; Balamurugan, A.; Saranti, A.; Karakassides, M.A.; Ferreira, J.M.F. Synthesis, bioactivity and preliminary biocompatibility studies of glasses in the system CaO-MgO-SiO2-Na2O-P2O5-CaF2. J. Mater. Sci. Mater. Med. 2011, 22, 217-227. [CrossRef]

21. Tulyaganov, D.U.; Makhkamov, M.E.; Urazbaev, A.; Goel, A.; Ferreira, J.M.F. Synthesis, processing and characterization of a bioactive glass composition for bone regeneration. Ceram. Int. 2013, 39, 2519-2526. [CrossRef]

22. Agathopoulos, S.; Tulyaganov, D.U.; Ventura, J.M.G.; Kannan, S.; Saranti, A.; Karakassides, M.A.; Ferreira, J.M.F. Structural analysis and devitrification of glasses based on the $\mathrm{CaO}-\mathrm{MgO}-\mathrm{SiO} 2$ system with B2O3, Na2O, CaF2 and P2O5 additives. J. Non-Cryst. Solids 2006, 352, 322-328. [CrossRef]

23. Hill, R.G.; Brauer, D.S. Predicting the bioactivity of glasses using the network connectivity or split network models. J. Non-Cryst. Solids 2011, 357, 3884-3887. [CrossRef]

24. Macon, A.L.; Kim, T.B.; Valliant, E.M.; Goetschius, K.; Brow, R.K.; Day, D.E.; Hoppe, A.; Boccaccini, A.R.; Kim, I.Y.; Ohtsuki, C.; et al. A unified in vitro evaluation for apatite-forming ability of bioactive glasses and their variants. J. Mater. Sci. Mater. Med. 2015, 26, 115. [CrossRef] [PubMed]

25. Beesk, W.; Jones, P.G.; Rumpel, H.; Schwarzmann, E.; Sheldrick, G.M. X-Ray crystal structure of Ag6O2. J. Chem. Soc. Chem. Commun. 1981, 664-665. [CrossRef]

26. Standke, B.; Jansen, M. Ag3O4, the First Silver (II, III) Oxide. Angew. Chem. Int. Ed. Engl. 1986, 25, 77-78. [CrossRef]

27. Norby, P.; Dinnebier, R.; Fitch, A.N. Decomposition of Silver Carbonate; the Crystal Structure of Two High-Temperature Modifications of Ag2CO3. Inorg. Chem. 2002, 41, 3628-3637. [CrossRef]

28. Suh, I.K.; Ohta, H.; Waseda, Y. High-temperature thermal expansion of six metallic elements measured by dilatation method and X-ray diffraction. J. Mater. Sci. 1988, 23, 757-760. [CrossRef]

29. Amendola, V.; Bakr, O.M.; Stellacci, F. A Study of the Surface Plasmon Resonance of Silver Nanoparticles by the Discrete Dipole Approximation Method: Effect of Shape, Size, Structure, and Assembly. Plasmonics 2010, 5, 85-97. [CrossRef]

30. Hu, S.; Chang, J.; Liu, M.; Ning, C. Study on antibacterial effect of $45 \mathrm{~S} 5$ Bioglass ${ }^{\circledR}$. J. Mater. Sci.-Mater. Med. 2009, 20, 281-286. [CrossRef]

31. Brauer, D.S. Bioactive Glasses-Structure and Properties. Angew. Chem. Int. Ed. 2015, 54, 4160-4181. [CrossRef]

32. Wang, X.; Wu, H.-F.; Kuang, Q.; Huang, R.-B.; Xie, Z.-X.; Zheng, L.-S. Shape-Dependent Antibacterial Activities of Ag2O Polyhedral Particles. Langmuir 2010, 26, 2774-2778. [CrossRef] [PubMed]

33. Evanoff, D.D.; Chumanov, G. Size-Controlled Synthesis of Nanoparticles. 1. "Silver-Only" Aqueous Suspensions via Hydrogen Reduction. J. Phys. Chem. B 2004, 108, 13948-13956. [CrossRef]

34. Aronne, A.; Sigaev, V.N.; Champagnon, B.; Fanelli, E.; Califano, V.; Usmanova, L.Z.; Pernice, P. The origin of nanostructuring in potassium niobiosilicate glasses by Raman and FTIR spectroscopy. J. Non-Cryst. Solids 2005, 351, 3610-3618. [CrossRef]

35. Omori, K. Analysis of the Infrared Absorption Spectrum of Diopside. Am. Mineral. 1971, 56, 1607-1616.

36. Stoch, L.; Środa, M. Infrared spectroscopy in the investigation of oxide glasses structure. J. Mol. Struct. 1999, 511,77-84. [CrossRef]

37. Begum, S.; Johnson, W.E.; Worthington, T.; Martin, R.A. The influence of $\mathrm{pH}$ and fluid dynamics on the antibacterial efficacy of $45 S 5$ Bioglass. Biomed. Mater. 2016, 11, 15006. [CrossRef]

38. Vecstaudza, J.; Gasik, M.; Locs, J. Amorphous calcium phosphate materials: Formation, structure and thermal behaviour. J. Eur. Ceram. Soc. 2019, 39, 1642-1649. [CrossRef]

39. Božanić, D.K.; Trandafilović, L.V.; Luyt, A.S.; Djoković, V. 'Green' synthesis and optical properties of silver-chitosan complexes and nanocomposites. React. Funct. Polym. 2010, 70, 869-873. [CrossRef]

40. Villars, P.; Cenzual, K. Pearson's Crystal Data-Crystal Structure Database for Inorganic Compounds; ASM International: Materials Park, OH, USA, 2010. 
41. Lellouche, J.; Kahana, E.; Elias, S.; Gedanken, A.; Banin, E. Antibiofilm activity of nanosized magnesium fluoride. Biomaterials 2009, 30, 5969-5978. [CrossRef]

42. Marquis, R.E. Antimicrobial actions of fluoride for oral bacteria. Can. J. Microbiol. 1995, 41, 955-964. [CrossRef]

Publisher's Note: MDPI stays neutral with regard to jurisdictional claims in published maps and institutional affiliations.

(C) 2020 by the authors. Licensee MDPI, Basel, Switzerland. This article is an open access article distributed under the terms and conditions of the Creative Commons Attribution (CC BY) license (http://creativecommons.org/licenses/by/4.0/). 